\title{
Disaccharidase deficiencies
}

\author{
G. NEALE
}

From the Department of Medicine, Royal Postgraduate Medical School, Du Cane Road, London

Up to 12 years ago the absorption of disaccharides was a problem in physiology which attracted little attention and which appeared to be unrelated to the problems of clinical medicine. Indeed, most textbooks stated incorrectly that the disaccharides were hydrolysed to monosaccharides in the lumen of the small intestine despite the evidence of half a century before, which had suggested that they were digested by the mucosal surface (Reid, 1901). The renewal of interest in the subject of disaccharide absorption occurred after the description of congenital lactase deficiency by Holzel, Schwarz, and Sutcliffe (1959) and of sucrase-isomaltase deficiency by Weijers, van de Kamer, Mossel, and Dicke (1960). Since then, there have been many hundreds of papers on intestinal disaccharidase deficiencies. The present paper describes the diagnosis, the incidence, and the causation of the disaccharidase deficiencies in man.

\section{The Enzymes}

The specific enzymes which hydrolyse dietary disaccharides have been localized to the enterocytic brush border. Attempts made to isolate these enzymes have yielded a variable number of fractions depending on the techniques used (Dahlquist, Auricchio, Semenza, and Prader, 1963; Semenza, Auricchio, and Rubino, 1965; Dahlquist and Telenius, 1969).

For clinical and pathological purposes, however, the terms maltase, isomaltase, sucrase, and lactase are used to describe the hydrolytic activities of the brush border of the enterocyte (Table I). All separative techniques applied to intestinal mucosal homogenates have produced more than one fraction

\begin{tabular}{|c|c|c|}
\hline Enzyme Activity & $\begin{array}{l}\text { Linkage } \\
\text { Hydrolysed }\end{array}$ & $\begin{array}{l}\text { Monosaccharides } \\
\text { Released }\end{array}$ \\
\hline $\begin{array}{l}\text { Maltase } \\
\text { Isomaltose }{ }^{1} \text { ( } a \text {-dextrinase) } \\
\text { Sucrase } \\
\text { Lactase }\end{array}$ & $\begin{array}{l}\alpha 1-4 \\
a 1-6 \\
\alpha 1-\beta 2 \\
\beta 1-4\end{array}$ & $\begin{array}{l}\text { Glucose } \\
\text { Glucose } \\
\text { Glucose and fructose } \\
\text { Glucose and galactose }\end{array}$ \\
\hline
\end{tabular}

Table I Disaccharidase activities of the enterocyte

${ }^{1}$ Little or no isomaltose is released from starch digestion in vivo. Nevertheless, the enzyme required for hydrolysis of a1-6 links in a-dextrins is customarily termed isomaltase. capable of hydrolysing maltose, which may explain why maltase deficiency is not found as an isolated defect of the enterocyte. Isomaltase and sucrase appear to be distinct but linked entities, and hence they are absent together in the hereditary condition of sucrase-isomaltase deficiency (Dahlquist and Telenius, 1969). Lactase activity consists of at least two separate enzymes, one of which is not in the brush border but within the cell (Zoppi, Hadorn, Gitzelmann, Kistler, and Prader, 1966). The significance of intracellular lactase activity is uncertain. It cannot play any part in the normal digestion of lactose which is a function of the brush border of the enterocyte. It may, however, explain why some lactase activity can usually be demonstrated in the mucosa of patients who fail to absorb lactose (McMichael, Webb, and Dawson, 1967).

\section{Hydrolysis of Disaccharides}

The hydrolysis of disaccharides is rapid and does not appear to be the rate-limiting step in the absorption of sugars except possibly for lactose (Gray and Santiago, 1966). Thus the measured concentration of enzyme activity in the brush border of the enterocyte bears little relationship to the rate of sugar absorption in normal subjects who are able to absorb lactose.

\section{Disaccharidase Deficiencies}

It is now well recognized that disaccharidase deficiency may produce symptoms in children and adults. The only common primary deficiency state is that of isolated lactase deficiency but its importance

\begin{tabular}{|c|c|c|}
\hline Enzyme Deficient & Variety & Comment \\
\hline Lactase & $\begin{array}{l}\text { Congenital } \\
\text { Acquired after } \\
\text { weaning }\end{array}$ & $\begin{array}{l}\text { Rare } \\
\text { Common; ethnically } \\
\text { determined }\end{array}$ \\
\hline & $\begin{array}{l}\text { Congenital } \\
\text { Acquired }\end{array}$ & $\begin{array}{l}\text { Rare; familial incidence } \\
\text { Unproven }\end{array}$ \\
\hline All disaccharidases & $\begin{array}{l}\text { Congenital } \\
\text { Acquired as a result } \\
\text { of mucosal damage }\end{array}$ & $\begin{array}{l}\text { Isolated case report } \\
\text { Lactase activity may be } \\
\text { most affected }\end{array}$ \\
\hline
\end{tabular}

Table II Classification of the disaccharidase deficiencies 
as a cause of symptoms remains controversial (Klotz and Lubos, 1967; Neale, 1968). The various types of disaccharidase deficiency may be characterized as seen in Table II.

\section{Diagnosis of Disaccharidase Deficiency}

\section{ORAL TOLERANCE TEST}

The rise in true blood glucose after the ingestion of lactose was used by Holzel et al (1959) to demonstrate lactose malabsorption and this method has been adapted for investigating the absorption of other disaccharides. After an oral dose of $50 \mathrm{~g}$ disaccharide, the blood glucose in normal subjects usually rises at least $20 \mathrm{mg}$ per $100 \mathrm{ml}$ above fasting levels. In patients with disaccharidase deficiency the increment of blood glucose is usually less than $20 \mathrm{mg} / 100 \mathrm{ml}$. This method of diagnosis is remarkably accurate despite the unknown variables such as the speed of the gastric emptying, rate of monosaccharide absorption, and the clearance of glucose from the blood. In a careful study of the value of 'tolerance' tests, McGill and Newcomer (1967) showed that they correctly predict absorption or malabsorption in $80 \%$ of cases. False positive results are most likely to occur using venous blood and false negative results occur with capillary blood. A blood sample should be taken 15 minutes after the ingestion of the disaccharide as well as at half-hourly intervals for two hours to detect the early rise in blood glucose which occurs in patients who empty their stomachs rapidly. Small infants should be given $2 \mathrm{~g} / \mathrm{kg}$ body weight but in adults there is no value in varying the dose of disaccharide according to the body weight. It is worthwhile assessing patients' symptoms during a 'tolerance' test. Most patients who cannot absorb the ingested disaccharide will complain of abdominal discomfort, flatulence, or occasionally diarrhoea.

\section{RADIOLOGICAL TEST}

Disaccharide malabsorption may be demonstrated on a radiograph of the abdomen taken one hour after the ingestion of a mixture of about $120 \mathrm{ml}$
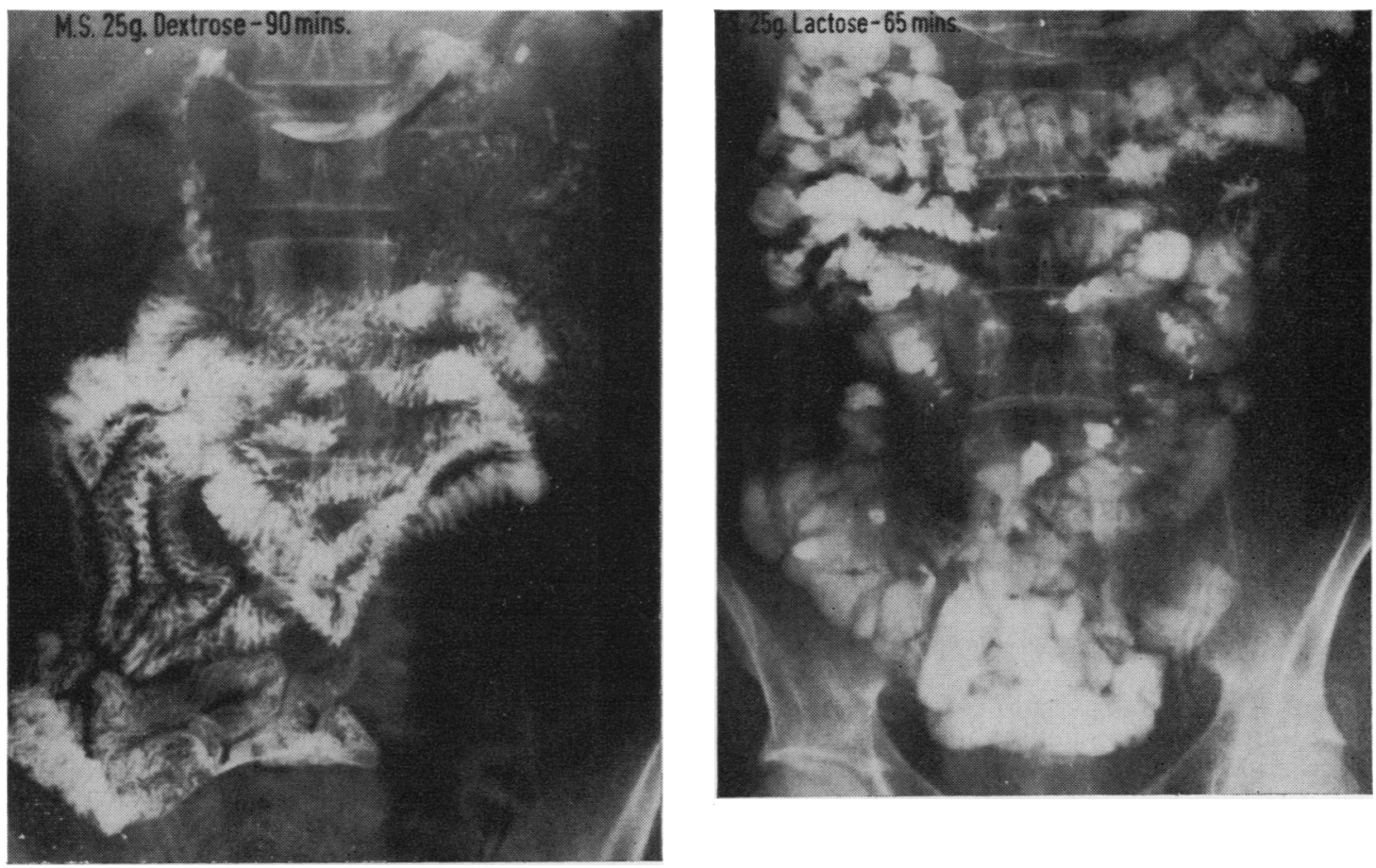

Fig. 1 Normal radiographic appearance of the intestine in a patient with hypolactasia given $120 \mathrm{ml}$ Micropaque containing $25 \mathrm{~g}$ dextrose (film taken at $90 \mathrm{~min}$ ).

Fig. 2 Radiographic appearance of intestine in the same patient as in Fig. 1 given 120 ml Micropaque containing $25 \mathrm{~g}$ lactose. Film taken at 60 min shows dilution of contrast medium, dilatation of small intestine, and head of the barium column in the distal colon. 
Micropaque and $25 \mathrm{~g}$ disaccharide. If the disaccharide is freely absorbed, the radiological appearances will not differ from those found when the patient is given Micropaque alone; if the disaccharide is unabsorbed, the contrast medium will be diluted by the influx of fluid into the small intestine. In addition, the small bowel may appear dilated and barium will appear in the colon in less than 60 minutes (Figs. 1 and 2). This test is as accurate as a 'tolerance' test (Laws, Spencer, and Neale, 1967).

MEASUREMENT OF DISACCHARIDASE ACTIVITY OF THE ENTEROCYTE

Direct measurements of the disaccharidase activities of homogenized intestinal mucosa may be made on fragments of intestinal mucosa weighing as little as $10 \mathrm{mg}$ (Dahlquist et al, 1963). The results are expressed as $\mu$ moles of disaccharide hydrolysed per minute at $37^{\circ} \mathrm{C}$ proportionate to the amount of mucosa used in the assay. Many workers have expressed their results per gram of mucosal protein but for clinical purposes equally valuable results are obtained by expressing the activity per gram of wet mucosa (the specimen having been cleaned and blotted). Mucosa obtained at surgery gives less reproducible results than peroral biopsy material. Moreover, a fragment of jejunal mucosa is not always representative of the whole of the small intestine and hence results have to be interpreted with caution. For comparative purposes, it is essential to obtain mucosa from as close to the duodenojejunal flexure as possible, because disaccharidase activity is not uniform throughout the small intestine. Newcomer and McGill (1966) have shown a marked increase in enzyme activity towards the middle of the small intestine and a fall-off towards the ileum. The ratios between disaccharidase activities may be of more value than absolute concentrations (Prader and Auriccio, 1965), and enzyme results should always be interpreted in conjunction with tests of absorption.

\section{OTHER TESTS}

\section{Collection of expired metabolites of ingested disac- charides}

Salmon, Read, and McCarthy (1969) have collected expired air after the administration of ${ }^{14} \mathrm{C}$-labelled disaccharide and measured the excretion of ${ }^{14} \mathrm{CO}_{2}$. This correlates well with other methods of demonstrating disaccharidase deficiency. Calloway, Murphy, and Bauer (1969) obtained similar results when they measured hydrogen excretion in expired air after the ingestion of sugar.

Stool tests

Infants with disaccharide malabsorption often pass watery stools having a $p \mathbf{H}$ of less than 5.5 and 7 containing both disaccharide (Kerry and Anderson, $\frac{0}{*}$ 1964) and lactic acid (Weijers et al, 1960). In older $\underline{\sigma}$ children and adults, however, stool examination gives very variable results and is not useful as a $\stackrel{\vec{D}}{\rightarrow}$ diagnostic procedure.

\section{Urine tests}

The finding of lactosuria after an oral dose of lactose is not uncommon in children with lactose malabsorption but may also occur in normal subjects who empty their stomachs very rapidly and in patients with a damaged intestinal mucosa.

\section{The Incidence and Causation of Disaccharidase Deficiency}

CONGENITAL

Simple congenital disaccharidase deficiencies of lactase or of sucrase-isomaltase are rare conditions 0 which have been discussed by Anderson (1971).

\section{ACQUIRED}

\section{Lactase deficiency}

Lactase deficiency as a characteristic acquired some- $\vec{\varphi}$

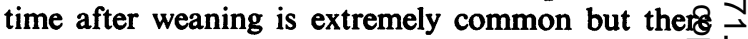
are striking differences in the incidence of this condition among various ethnic groups (Table III Simoons (1969 and 1970) has made an interestin attempt to explain these findings. He points out that it is likely that milk was first used by man in the near and middle East and in north Africa about 5,000 to 6,000 years ago. By classical times, the habit of drinking milk was also common in Europe and had extended into north-west India. On the other hand, the indigenous populations of the rest of the world did not ingest milk. It is possible to correlate these cultural differences with the presentday incidence of adult milk intolerance (Fig. 3). Thus there is a high incidence of intolerance in the traditional non-milk drinking areas in east and southeast Asia and amongst the indigenous peoples of the Americas, Australasia, the Pacific islands, and possibly India. In tropical Africa the non-Bantu pastoralists (whose forefathers almost certainly came from north Africa or the regions of the Nile) $\sigma$ are usually able to absorb lactose whilst the Bantu agriculturalists are usually unable to do so (Cook and Kajubi, 1966). In the traditional milk-drinking areas of Europe the incidence of lactose intolerance is less than $20 \%$ in most populations studied so far. Somewhat paradoxically, McMichael, Webb, and Dawson (1966) found that many Greeks were unable to absorb lactose, and to explain this finding, Simoons (1970) had to make the special plea that the 


\begin{tabular}{|c|c|c|c|c|}
\hline Investigators & Group Studied & No. Studied & $\begin{array}{l}\text { No. Lactase Deficient or } \\
\text { Lactose Intolerant }\end{array}$ & $\begin{array}{l}\text { Percentage } \\
\text { Incidence }\end{array}$ \\
\hline $\begin{array}{l}\text { Aurricchio et al (1963) } \\
\text { Neale (1968) } \\
\text { Gudmand-Höyer, Dahlquist, and Jarnum (1969) } \\
\text { McMichael } \text { et al (1966) }\end{array}$ & $\begin{array}{l}\text { European } \\
\text { Swiss (patients with duodenal ulcer) } \\
\text { English (hospital outpatients) } \\
\text { Danish (hospital inpatients) } \\
\text { Greeks (in London) } \\
\text { American white people }\end{array}$ & $\begin{array}{r}18 \\
50 \\
700 \\
17\end{array}$ & $\begin{array}{l}3 \\
3 \\
16-46^{1} \\
15\end{array}$ & $\begin{array}{r}17 \\
6 \\
2-7^{1} \\
90\end{array}$ \\
\hline $\begin{array}{l}\text { Sheehy and Anderson (1965) } \\
\text { Bayless and Rosensweig (1966) } \\
\text { Newcomer and McGill (1967) } \\
\text { Welsh, Rohrer, Knudsden, and Paustian (1967) }\end{array}$ & $\begin{array}{l}\text { Healthy servicemen } \\
\text { Prisoners } \\
\text { Healthy volunteers } \\
\text { Hospital patients }\end{array}$ & $\begin{array}{r}50 \\
16 \\
100 \\
145\end{array}$ & $\begin{array}{r}8 \\
1 \\
6 \\
27\end{array}$ & $\begin{array}{r}16 \\
6 \\
6 \\
19\end{array}$ \\
\hline Bolin, Crane, and Davis (1968) & $\begin{array}{l}\text { Australians (European origin) } \\
\text { Healthy volunteers }\end{array}$ & 23 & $\mathbf{0}$ & $\mathbf{0}$ \\
\hline $\begin{array}{l}\text { Bolin et al (1968) } \\
\text { Chung and McGill (1968) }\end{array}$ & $\begin{array}{l}\text { Oriental } \\
\text { Chinese (in Australia) } \\
\text { Chinese, Koreans, Japanese } \\
\text { (in USA) }\end{array}$ & $\begin{array}{l}21 \\
11\end{array}$ & $\begin{array}{l}18 \\
11\end{array}$ & $\begin{array}{r}86 \\
100\end{array}$ \\
\hline Flatz et al (1969) & Thailanders & 75 & 75 & 100 \\
\hline $\begin{array}{l}\text { Cuatrecasas et al (1965) } \\
\text { Bayless and Rosensweig (1966) } \\
\text { Cook and Kajubi (1966) } \\
\text { Jersky and Kinsley (1967) } \\
\text { Cook and Kajubi (1966) }\end{array}$ & $\begin{array}{l}\text { African } \\
\text { American negro } \\
\text { American negro (prisoners) } \\
\text { Bantu (Uganda) } \\
\text { Bantu (South Africa) } \\
\text { Non-Bantu (Uganda) }\end{array}$ & $\begin{array}{l}41 \\
20 \\
55 \\
38 \\
51\end{array}$ & $\begin{array}{l}30 \\
14 \\
49 \\
35 \\
13\end{array}$ & $\begin{array}{l}73 \\
70 \\
90 \\
90 \\
25\end{array}$ \\
\hline $\begin{array}{l}\text { Elliott, Maxwell, and Vawser (1967) } \\
\text { Bolin et al (1968) } \\
\text { Welsh et al (1967) } \\
\text { Alzate, González, and Guzmán (1969) } \\
\text { Gudmand-Höyer and Jarnum (1969) }\end{array}$ & $\begin{array}{l}\text { Indigenous people of other areas } \\
\text { Australian aboriginal children } \\
\text { New Guinea } \\
\text { North American Indians } \\
\text { Chami Indians (Colombia) } \\
\text { Eskimos (Greenland) }\end{array}$ & $\begin{array}{r}324 \\
8 \\
3 \\
24 \\
25\end{array}$ & $\begin{array}{l}\text { Not stated } \\
8 \\
2 \\
14 \\
22\end{array}$ & $\begin{array}{r}80 \\
100 \\
67 \\
58 \\
88\end{array}$ \\
\hline
\end{tabular}

\section{Table III Incidence of lactase deficiency or of lactose intolerance amongst normal peoples}

${ }^{1}$ Of the 700 subjects 46 had lactose deficiency. In 18 subjects this was an isolated finding and two of these 18 were Greenland Eskimos. The other 28 were patients with gastrointestinal disease-peptic ulceration, gluten enteropathy, Crohn's disease, or ulcerative colitis.

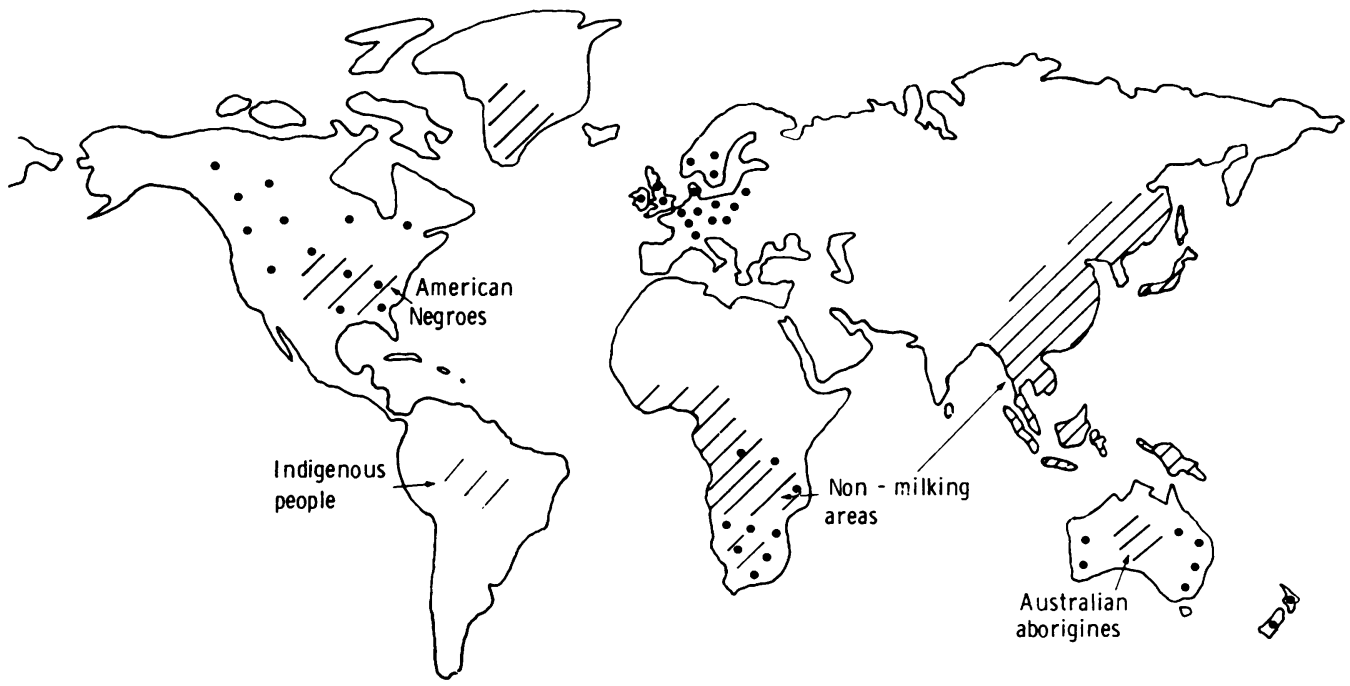

Areas with high incidence

of lactose malabsorption $\because \quad$ Areas with low incidence of lactose malabsorption
Fig. 3 Global distribution of lactosetolerant and lactose-intolerant peoples. 
average consumption of milk in south east Europe had never been high.

Most workers believe that there is an inherited basis for acquired adult lactose intolerance (Ferguson and Maxwell, 1967). The main alternative theory is that the defect reflects a low level of milk consumption resulting in a gradual adaptive decline in enzyme activity (Bolin and Davis, 1969). Evidence cited in favour of the genetic theory includes: (1) a lack of correlation between milk ingestion and lactose intolerance (Dunphy, Littman, Hammond, Forstner, and Maxwell, 1965; Flatz, Saenguidom, and Sanguanbhokhai, 1969); (2) normal lactase activity in nine patients with galactosaemia denied lactose from birth (Kogut, Donnell, and Shaw, 1967); and (3) no consistent change in lactase activity in lactose-tolerant subjects denied lactose (Knudsen, Welsh, Kronenberg, Vanderveen, and Heidlebaugh, 1968; Rosensweig and Herman, 1969) or in lactoseintolerant subjects fed lactose (Cuatrecasas, Lockwood, and Caldwell, 1965; Rosensweig and Herman, 1969).

On the other hand, Bolin Davis, Seah, Chua, Yong, Kho, Siak, and Jacób (1970) have shown that Chinese children under 10 years old living in Singapore who are milk drinkers have a lower incidence of lactase deficiency than a similar group of non-milk drinking children with the same ethnic background. Further studies on the effect of prolonged lactose feeding may help to decide if primary lactase deficiency is an adaptive condition in man.

Studies in animals have also led to confusing results but it seems that the normal fall in lactase activity after weaning can be delayed by giving lactose and that it is sometimes possible to raise lactase activity by feeding large quantities of lactose (Bolin, Pirola, and Davis, 1969). Broitman, Thalenfeld, and Zamcheck (1968), however, could not demonstrate improved lactose absorption in adult animals in which lactose feeding had induced higher concentrations of lactase. Moreover, the relevance of such studies to the human situation is questionable because very high concentrations of lactose have been used in the experimental diets given to animals.

\section{Isolated sucrase-isomaltase deficiency}

This is almost certainly never an acquired defect although subjects with this condition occasionally do not present until adult life (Neale, Clark, and Levin, 1965; Pink, 1967). In contrast with lactase it is possible to increase the activities of both intestinal sucrase and maltase within two to five days in normal subjects by feeding either sucrose or fructose (Rosensweig and Herman, 1968). Glucose, galactose, and lactose have no effect. It is suggested that fructose acts as an inducer by binding to the sucrase- active hydrolytic site. The effect on maltase remains unexplained unless there is a joint sucrase-maltase enzyme system.

DISACCHARIDASE DEFICIENCIES SECONDARY TO OTHER DISEASES

In diseases such as gluten-sensitive enteropathy, in which there is damage to the intestinal mucosa, the cellular mechanisms for membrane digestion and for sugar absorption are often severely impaired. Malabsorption of all sugars may also occur as a transient phenomenon after an attack of gastroenteritis (Burke and Anderson, 1966). Although not all workers agree (Welsh, 1970), there is some evidence that the ability to hydrolyse lactose is particularly severely affected in patients with diffuse intestinal mucosal damage and is the last of the disaccharidases to recover (Plotkin and Isselbacher, 1964; Neale, 1968). In such patients, a reduction of dietary lactose may lead to an apparent improvement in symptoms.

It has also been suggested that a depression of lactase activity may be an acquired feature of many disorders, including Crohn's disease, ulcerative colitis, rosacea, and other skin conditions, and after gastrointestinal surgery. Lactose malabsorption, however, does not seem to be very common amongs patients with these conditions and when it is foundo it probably represents a chance association (Newcomer and McGill, 1967; Neale, 1968).

\section{The Clinical Significance of the Disaccharidase Deficiencies}

\section{LACTASE DEFICIENCY}

\section{Symptomatology}

There is a wide variation in the symptoms of patients with isolated lactase deficiency. Intestinal perfusion studies have shown a markedly reduced hydrolysis of lactose in vivo (McMichael et al, 1967). The unabsorbed lactose produces a net movement of fluid and electrolytes into the lumen of the small intestine in order to render its contents iso-osmotic with extracellular fluid. These changes may be visualized radiographically (Fig. 2) and lead to an accelerated transit of small-intestinal contents to the colon (Launiala, 1968). In the colon, lactose is hydrolysed by bacterial fermentation to lactic acid, carbon dioxide, and water, thereby temporarily increasing osmolarity and decreasing $\mathrm{pH}$.

These occurrences within the small intestine and the colon may be sufficient to explain the symptoms of which patients frequently complain-abdominal cramps, borborygmi, flatulence, and occasionally diarrhoea. Nevertheless, many subjects who fail to 
absorb lactose are symptom-free even though they drink some milk. In a study at Hammersmith, 35 out of 59 patients with hypolactasia, who had nonspecific abdominal symptoms for which no other cause could be found, complained of similar symptoms after ingesting $25 \mathrm{~g}$ lactose (ie, the equivalent of 1 pint of milk). Of these 35 patients, 24 stated that they drank more than half a pint of milk per day. The symptoms of 13 patients were lessened by reducing their milk intake.

\section{Associated disorders}

It has been suggested that lactase-deficient subjects may develop osteoporosis because they drink little milk and therefore take in little calcium (Birge, Keutmann, Cuatrecasas, and Whedon, 1967). This suggestion was not supported by a study at Hammersmith Hospital in which the incidence of hypolactasia in patients with osteoporosis was not significantly greater than that found in control subjects (Neale, 1968).

Steatorrhoea enhanced by intestinal hurry secondary to malabsorption of lactose has been described, especially in patients who have had gastric surgery (Bank, Barbezat, and Marks, 1966) or an intestinal resection (Kern, Struthers, and Attwood, 1963). In patients with an otherwise normal gastrointestinal tract, the absorption of nutrients seems to be little impaired. Nevertheless, the absorption of drugs may be delayed as shown for isoniazid or reduced as in the case of sulphafurazole (Jussila, Mattila, and Takki, 1970).

\section{SUCRASE-ISOMALTASE DEFICIENCY}

This is a rare condition and most of the patients are described as suffering from acid diarrhoea which is relieved by taking a diet free of sucrose. Not all patients show evidence of malabsorption of starch (Burgess, Levin, Mahalanabis, and Tonge, 1964) but if this is a problem, the starch of rice may be better tolerated than that of potatoes or of wheat because it contains more amylose and less amylopectin and therefore fewer a 1-6 links (Lindquist and Meeuwisse, 1966).

\section{Conclusion}

The disaccharidase deficiencies have provided a fertile area for many lines of research during the last decade. As a result of these studies, the clinical pathologist has little difficulty in assessing disaccharide absorption in healthy subjects and the clinician has been provided with a rational explanation for the symptoms of some patients with gastrointestinal complaints. Further work is necessary to elucidate how the enterocytic enzymes work, how they are produced, and how they are affected by variations in diet and by disease processes.

\section{References}

Alzate, H., González, H., and Guzmán, J. (1969). Lactose intolerance in South American indians. Amer. J. clin. Nutr., 22, 122-123.

Anderson, C. M. (1971). Disturbances of carbohydrate absorption in children. J. clin. Path., 24, Suppl. (Roy. Coll. Path.), 5, 14-21.

Auricchio, S., Rubino, A., Landolt, M., Semenza, G., and Prader, A. (1963). Isolated intestinal lactase deficiency in the adult. Lancet, 2, 324-326.

Bank, S., Barbezat, G. O., and Marks, I. N. (1966). Postgastrectomy steatorrhoea due to intestinal lactase deficiency. S. Afr. med.J., 40, 597-599.

Bayless, T. M., and Rosensweig, N. S. (1966). A racial difference in the incidence of disaccharidase deficiency. J. Amer. med. Ass., 197, 968-972.

Birge, S. J., Keutmann, H. T., Cuatrecasas, P., and Whedon, G. D. (1967). Osteoporosis, intestinal lactase deficiency and low dietary calcium intake. New Engl. J. Med., 276, 445-448.

Bolin, T. D., Crane, G. G., and Davis, A. E. (1968). Lactose intolerance and its various ethnic groups in South East Asia. Aust. Ann. Med., 17, 300-306.

Bolin, T. D., and Davis, A. E. (1969). Asian lactose intolerance and its relation to intake of lactose. Nature (Lond.), 222, 382-383.

Bolin, T. D., Davis, A. E., Seah, C. S., Chua, K. L., Yong, V., Kho, K. M., Siak, C. L., and Jacób, E. (1970). Lactose intolerance in Singapore. Gastroenterology, 59, 76-84.

Bolin, T. D., Pirola, R. C., and Davis, A. E. (1969). Adaptation of intestinal lactase in the rat. Gastroenterology, 57, 406-409.

Broitman, S. A., Thalenfeld, B. E., and Zamcheck, N. (1968). Alterations in gut lactase activity in young and adult rats fed lactose. (Abstr.). Fed. Proc., 27, 573.

Burgess, E. A., Levin, B., Mahalanabis, D., and Tonge, R. E. (1964). Hereditary sucrose intolerance: Levels of sucrase activity in jejunal mucosa. Arch. Dis. Childh., 39, 431-443.

Burke, V., and Anderson, C. M. (1966). The relationship of dietary lactose to refractory diarrhoea in infancy. Aust. paediat. J., 1, 147-151.

Calloway, D. H., Murphy, E. L., and Bauer, D (1969) Determination of lactose intolerance by breath analysis. Amer. J. dig. Dis., 14, 811-815.

Chung, M. H., and McGill, D. B. (1968). Lactase deficiency in orientals. Gastroenterology, 54, 225-226.

Cook, G. C., and Kajubi, S. K. (1966). Tribal incidence of lactase deficiency in Uganda. Lancet, 1, 725-730.

Cuatrecasas, P., Lockwood D. H., and Caldwell, J. R. (1965). Lactase deficiency in the adult. Lancet, 1, 14-18.

Dahlquist, A., Auricchio, S., Semenza, G., and Prader, A. (1963). Human intestinal disaccharidases and hereditary disaccharide intolerance. The hydrolysis of sucrose, isomaltose, palatinose (isomaltulose) and a 1,6-a-oligosaccharide preparation. J. clin. Invest., 42, 556-562.

Dahlquist, A., and Telenius, U. (1969). Column chromatography of human small intestinal maltase, isomaltase and invertase activities. Biochem. J., 111, 139-146.

Dunphy, J. V., Littman, A., Hammond, J. B., Forstner, G., Dahlquist, A., and Crane, R. K. (1965). Intestinal lactase deficit in adults. Gastroenterology, 49, 12-21.

Elliott, R. B., Maxwell, G. M. and Vawser, N. (1967). Lactase maldigestion in Australian aboriginal children. Med. J. Aust., 1, 46-49.

Ferguson, A., and Maxwell, J. D. (1967). Genetic aetiology of lactose intolerance. Lancet, 2, 188-190.

Flatz, G., Saenguidom, Ch., and Sanguanbhokhai, T. (1969). Lactose intolerance in Thailand. Nature (Lond.), 221, 758-759.

Gray, G. M., and Santiago, N. A. (1966). Disaccharide absorption in normal and diseased human intestine. Gastroenterology, 51, 489-498.

Gudmand-Höyer, E., Dahlquist, A., and Jarnum, S. (1969). Specific small intestinal lactase deficiency in adults. Scand.J. Gastroent., 4, 377-386.

Gudmand-Höyer, E. and Jarnum, S. (1969). Laktosemalabsorption hos grönlaendere. Ugeskr. Laeg., 131, 917-918.

Holzel, A., Schwarz, V., and Sutcliffe, K. W. (1959). Defective lactose absorption causing malnutrition in infancy. Lancet, 1, 11261128. 
Jersky, J., and Kinsley, R. H. (1967). Lastase deficiency in the South African Bantu. S. Afr. med. J., 41, 1194-1196.

Jussila, J., Mattila, M. J., and Takki, S. (1970). Drug absorption during lactose induced intestinal symptoms in patients with selective lactose malabsorption. Ann. Med. exp. Fenn., 48, 33-37.

Kern, F., Struthers, J. E., and Attwood, W. L. (1963). Lactose intolerance as a cause of steatorrhoea in an adult. Gastroenterology, 45, 477-487.

Kerry, K. R., and Anderson, C. M. (1964). A ward test for sugar in faeces. Lancet, 1, 981-982.

Klotz, A. P., and Lubos, M. C. (1967). Gastrointestinal symptoms and intestinal lactase deficiency-a word of caution. Amer. J. dig. Dis., 12, 421-423.

Knudsden, K. B., Welsh, J. D., Kronenberg, R. S., Vanderveen, J. E., and Heidelbaugh, N. D. (1968). Effect of a non-lactose diet on human intestinal disaccharidase activity. Amer. J. dig. Dis., 13, 593-597.

Kogut, M. D., Donnell, G., and Shaw, K. N. F. (1967). Studies of lactose absorption in patients with galactosaemia. J. Pediat., $71,75-81$.

Launiala, K. (1968). The effect of unabsorbed sucrose and mannitol on the small intestinal flow rate and mean transit time. Scand. J. Gastroent., 3, 665-671.

Laws, J. W., Spencer, J., and Neale, G. (1967). Radiology in the diagnosis of disaccharidase deficiency. Brit. J. Radiol., ns 40, 594-603.

Lindquist, B., and Meeuwisse, G. W. (1966). Diets in disaccharidase deficiency and defective monosaccharide absorption. J. Amer. diet. Ass., 48, 307-310.

McGill, D. B., and Newcomer, A. D. (1967). Comparison of venous and capillary blood samples in lactose tolerance testing. Gastroenterology, 53, 371-374.

McMichael, H. B., Webb, J., and Dawson, A. M. (1966). Jejunal disaccharidases and some observations on the cause of lactase deficiency. Brit. med. J., 2, 1037-1041.

McMichael, H. B., Webb, J., and Dawson, A. M. (1967). The absorption of maltose and lactose in man. Clin. Sci., 33, 135-145.

Neale, G., Clark, M., and Levin, B. (1965). Intestinal sucrase deficiency presenting as sucrose intolerance in adult life. Brit. med. J., 2, 1223-1225.

Neale, G. (1968). The diagnosis incidence and significance of disaccharidase deficiency. Proc. roy. Soc. Med., 61, 1099-1102.

Newcomer, A. D., and McGill, D. B. (1966). Distribution of disaccharidase activity in the small bowel of normal and lactasedeficient subjects. Gastroenterology, 51, 481-488.
Newcomer, A. D., and McGill, D. B. (1967). Incidence of lactase deficiency in ulcerative colitis. Gastroenterology, 53, 890-893.

Pink, I. J. (1967). Diarrhoea due to sucrase and isomaltase deficiency. Gut, 8, 373-376.

Plotkin, G. R., and Isselbacher, K. J. (1964). Secondary disaccharidase deficiency in adult celiac disease (non-tropical sprue) and other malabsorption states. New Engl. J. Med., 271, 1033-1037.

Prader, A., and Auricchio, S. (1965). Defects of intestinal disaccharide absorption. Ann. Rev. Med., 16, 345-358.

Reid, E. W. (1901). Intestinal absorption of maltose. J. Physiol.(Lond.). 26, 427-435.

Rosensweig, N. S., and Herman, R. H. (1968). Control of jejunal sucrase and maltase activity by dietary sucrose or fructose in man. A model for the study of enzyme regulation in man. \& J. clin. Invest. 47, 2253-2262.

Rosensweig. N. S., and Herman, R. H. (1969). Diet and disacchari- $\vec{O}$ dases. Amer. J. clin. Nutr., 22, 99-102.

Salmon, P. R., Read, A. E., and McCarthy, C. F. (1969). An isotope technique for measuring lactose absorption. Gut, 10, 685-689.

Semenza, G., Auricchio, S., and Rubino, A. (1965). Multiplicity of human intestinal disaccharidases. I. Chromatographic separ- 긍 ation of maltases and of two lactases. Biochem. Biophys. Acta, is
96, 487-497.

Sheehy, T. W., and Anderson, P. R. (1965). Disaccharidase activity or in normal and diseased small bowel. Lancet, 2, 1-4.

Simoons, F. J. (1969). Primary adult lactose intolerance and the milking habit: A problem in biological and cultural inter- $N$ relations. I Review of the medical research. Amer. J. dig. Dis., 음 14, 819-836.

Simoons, F. J. (1970). Primary adult lactose intolerance and the milking habit: A problem in biological and cultural interrelations. II A culture-historical hypothesis. Amer. J. dig. Dis., $15,695-710$

Weijers, H. A., van de, Kamer, J. H. Mossel, D. A. A., and Dicke, W. K. (1960). Diarrhoea caused by deficiency of sugarsplitting enzymes. Lancet, 2, 296-297.

Welsh, J. D. (1970). Lactase deficiency in humans. Medicine (Ba/R more), 49, 257-277.

Welsh, J. D., Rohrer, V., Knudsen, K. B., and Paustian, F. F. (196 Isolated lactase deficiency: Correlation of laboratory studic and clinical data. Arch. intern. Med., 120, 261-269.

Zoppi, G., Hadorn, B., Gitzelmann, R., Kistler, H., and Prader, A. (1966). Intestinal $\beta$-galactosidase activities in malabsorption syndromes. Gastroenterology, 50, 557-561. 